\title{
Colorectal Cancer and the Preventive Effects of Food Components
}

\author{
Sayori Wada \\ Kyoto Prefectural University \\ Japan
}

\section{Introduction}

It has been reported that the cause of $30 \%$ of cancer is associated with eating habits (Anand et al., 2008). Colorectal cancer is one of the most common causes of death all over the world, and there is a strong association between this type of cancer and food intake. Despite this statement, the preventive effects of foods and nutrients on colorectal cancer have not completely elucidated yet.

It has been proposed that some biologically active nutrients suppress colon carcinogenesis through the mechanisms of cytostatic properties, inhibition of cell growth, induction of apoptosis, an anti-inflammation effect or modification of DNA in in vitro studies.

Although the positive effects of these nutrients have been shown in in vitro studies, it is still difficult to apply the effects of these nutrients in in vivo studies, due to modifications to foods during the process of absorption and delivery within the body. There might be two possible active sites, where foods and their components affect colon epithelium cells, where nutrients are distributed hematogenously after absorption, or retained in the lumen without absorption. Absorbed foods and nutrients might show the effects of anti-inflammation, antioxidant, and anti-proliferative par hematogenously in cancer epithelial cells and stromal cells, while on the other hand, the regulation of enterobacteria might be provided by the component in a poorly-absorbed form. Recent studies have focused on resistant carbohydrates functioning as prebiotics that prevent colorectal cancer (Davis \& Milner, 2009).

The normal human intake of food has a great advantage for oral administration and safety, compared with the administration of medicine, because safety has been proven by long food experience. Thus, the prevention of colorectal cancer through the intake of specific foods and nutrients might have a great potential, however further studies are required, especially in regard to absorption and disposition. In this paper, we focused on foods, and their components, with cancer preventive aspects.

\section{The preventive effects of food components against colorectal cancer}

Colorectal cancer is one of the most common cancers in the world and it has been proposed that it is strongly associated with dietary habits (Anand et al., 2008; Jemal et al., 2011). Red and processed meat may convincingly increase the risk, and physical activity is only the 
proven method of prevention. Avoiding body fatness, especially abdominal fatness, and the consumption of an excessive amount of alcohol are also important for colorectal cancer prevention (World Cancer Research Fund, 2007b). Despite the confirmation of cancer inducing foods, foods or nutritional elements that have protective qualities against colorectal cancer have not yet been fully confirmed.

\subsection{Epidemiology}

Colorectal cancer is the third most commonly diagnosed cancer in males and the second in females, and it is the fourth common cause of death in males and third in females, according to a survey conducted in 2008 (Jemal et al., 2011) . The increasing rate of colorectal cancer is considered to be due to the combination of changes in dietary patterns, obesity and smoking (Jemal et al., 2011). Approximately only 5-10\% of all colorectal cancers are a consequence of recognized hereditary conditions (Lynch \& de la Chapelle, 2003). Since dietary habits play an important role in the incidence of colorectal cancer, this subject must be employed as one of the main strategies to investigate components derived from foods with cancer prevention properties.

It has been reported that dietary patterns are associated with the onset of colorectal cancer. The Mediterranean diet was associated with a reduced risk of recurrence of colorectal adenomas in woman. The Mediterranean diet is characterized by a high consumption of breads, vegetables, fruit, fish and olive oil (World Cancer Research Fund, 2007c, as cited in Cottet et al., 2005). The Japanese traditional diet is characterized by a high consumption of fish and seafood with a high salt content. Japanese cohort studies demonstrated that both the Japanese traditional diet and western diet were associated with an increased risk of colon cancer in women, but not in men (Kim et al., 2005). The 'Pork, processed meats and potatoes' diet was associated with an increased risk of colon cancer in women and also with rectal cancer in men. 'Pork, processed meats and potatoes' diet pattern was characterized as intakes of energy, protein carbohydrate, fat, saturated and monounsaturated fatty acids, cholesterol, B vitamins, and minerals (Dixon et al., 2004). Vegetarian diets might moderately reduce the risk of colon cancer, which is due to not only to no or low consumption of meat, but also to a high consumption of plant foods (Sanjoaquin et al., 2004; World Cancer Research Fund, 2007c), although there is a negative result of colorectal cancer prevention (Key et al., 1996).

\subsection{Adenoma-to-carcinoma sequence and pathology}

A genetic model for colorectal tumorigenesis has been proposed in the following procedures (Fearon \& Vogelstein, 1990). 1) The mutation of APCTS gene transform normal colonic epithelia tissue to multiple polyps, 2) DNA hypomethylation is related to the onset and development of and early adenoma, 3) The K-ras oncogene play an important role in the progression from early to intermediate adenomas, 4) A mutation of the Thymidylate synthase gene plays an important role in the development from intermediate to late adenoma, 5) A mutation of TP53 gene is highly found in late adenomas and colorectal cancers (Tammariello \& Milner, 2010) (Figure 1).

Oxidative stress, which provided by both exogenous (irradiation, chemicals, and drugs) and endogenous (O2 metabolism, immune response, and inflammation) origin, plays a critical 


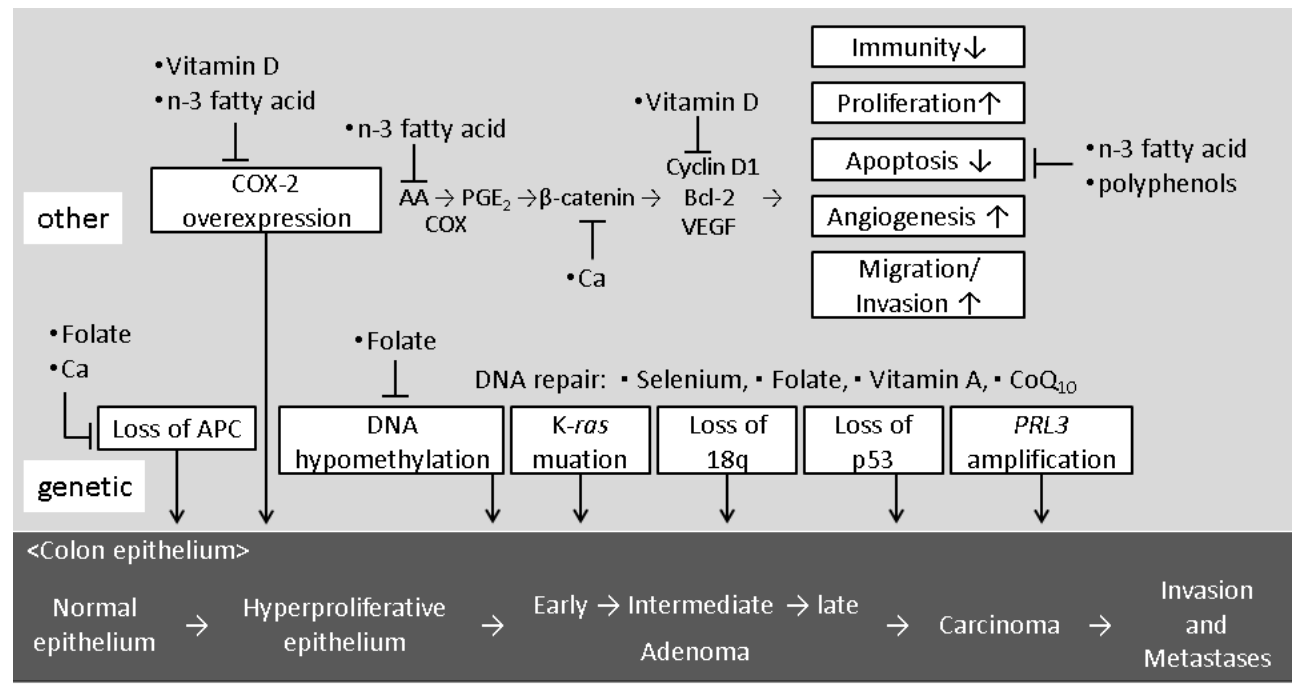

$<$ Intestinal lumen>
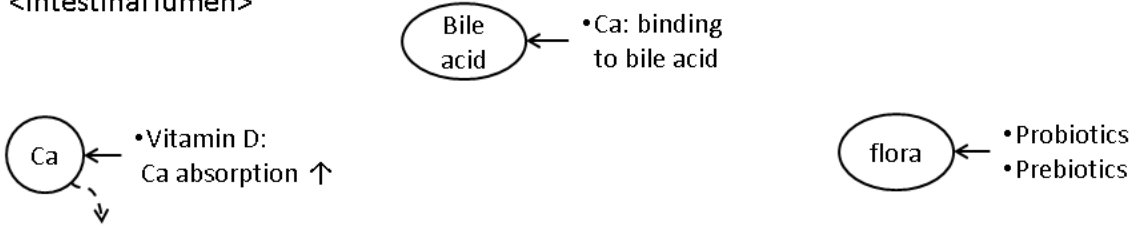

Abbreviations: COX, cyclooxygenase; AA, arachidonic acid; VEGF vascular endothelial growth factor; $\mathrm{Ca}$, calcium; $\mathrm{CoQ}_{10}$, coenzyme $\mathrm{Q}_{10}$

Fig. 1. Proposed anticarcinogenetic effects of nutrients on colorectal cancer. Selenium, folate, vitamin $A$ and $\mathrm{CoQ}_{10}$ have been reported to repair damaged DNA. Vitamin D and n-3 fatty acid may suppress the COX-2 mediated carcinogenesis. Ca plays a diverse role, including the inhibition of APC mutation, suppression of $\beta$-catenin and binding to bile acid. Probiotics and/or prebiotics reduce colorectal cancer to modify the proportion of gut microflora.

role in DNA damage (Kryston et al., 2011). Reactive oxygen spices (ROS) and DNA interactions induce DNA damage, which causes mutation via either double-strand break (DSB) or non-DSB lesions (Sedelnikova et al., 2010). Carcinogenesis of oxidative stress also involve immune cell activation via CCL2/MCP-1, pro-inflammatory factor (Martin et al., 2011).

The methods of accurate measurement of oxidative stress have been brought by HPLC, tandem mass spectrometry (MS/MS) electrochemical detector (Cadet et al., 2010). There are also biomarkers to assess the level of oxidative stress, such as 8-oxo-2' deoxyguanosine (8oxo-dG) (Ziech et al., 2010). These can allow us precise studies of anti-oxidative property by food.

Cyclooxygenase (COX) also plays an important role in carcinogenesis, e.g. to induce prostaglandin $\mathrm{E}_{2}\left(\mathrm{PGE}_{2}\right)$. $\mathrm{PGE}_{2}$ has diverse functions to promote cell proliferation, migration, 
invasion and angiogenesis, and also to suppress immunity and apoptosis through inducing cyclin D1, Bcl-2 and vascular endothelial growth factor (VEGF) (Chan \& Giovannucci, 2010). Figure 1 demonstrates the possible anti-tumor mechanisms of nutrients in the process of colorectal carcinogenesis (Janne \& Mayer, 2000; Lamprecht \& Lipkin, 2003; World Cancer Research Fund, 2007a; Chan \& Giovannucci, 2010; Vilar \& Gruber, 2010).

\subsection{Digestion, absorption, delivery and distribution, and the site of mechanisms of action}

For the clinical application of foods and nutrients for the prevention of colorectal cancer, we need to elucidate thoroughly how each food is digested, absorbed, delivered, and distributed to every organ or tissue, and determine what is the biologically active component, similar to the pharmacokinetics of drugs. Food constituents showed anti-tumor properties when they are distributed hematogenously to pre-cancer or cancer epithelial cells.

We often find that there is a big gap in the effective concentration between in vitro and in vivo studies. It sometimes happens that in vitro studies need a much higher concentration to demonstrate significant anti-tumor effects, compared with the biological concentration. When the ingestion of a nutrient shows a cancer prevention effect in an in vivo study, this does not directly mean the nutrient affect will be imported into the cells, as it may change to another form after digestion and absorption. Each article of food includes a lot of constituents, so that various constituents may demonstrate additive action or synergetic effects. In addition, active constituents affect not only cancer epithelium cells, but also the cancer stromal environment, e.g. angiogenesis or the interaction between epithelial and stromal cells, since the paracrine interaction between epithelial and stroma cells affect each other for tumor progression (Ko et al., 2002; Adegboyega et al., 2004; Martinez-Outschoorn et al., 2011).

For cancer prevention of the alimentary tract, active food components can have an effect not only hematogenously, but also from the gut lumen side. This indicates that indigestible constituents, as well as easily absorbed components, can function as potent anti-cancer agents against colorectal cancer. As mentioned above, resistant starches have cancer prevention properties as prebiotics that modify intestinal microorganism (Tuohy et al., 2005). Calcium may reduce the colorectal cancer risk associated with the combination to bile acid, the risk profile in intestinal lumen (Boursi \& Arber, 2007). The effective site of food components has been proposed in Figure 1 (Lamprecht \& Lipkin, 2003).

Some of the blood levels of active components after the ingestion of foods have been reported, but those amounts in the gut or stool have been rarely reported. For colorectal cancer prevention in humans, we need to investigate the systemic function of food ingredients, how the food is digested, absorbed and remains in the gut, as well as the blood concentration and delivery in each organ. Further studies are necessary to illuminate the mechanisms of food components on colorectal cancer prevention.

\subsection{Food, nutrition, physical activity and the prevention of cancer: a global perspective, 2007}

The Food, Nutrition, Physical Activity and the Prevention of Cancer: a Global Perspective was produced by the World Cancer Research Fund and the AIRC, in order to generate a 
comprehensive series of recommendations on food, nutrition, and physical activity, for reducing cancer risk for all populations worldwide (World Cancer Research Fund, 2007b).

The World Cancer Research Fund and the American Institute for Cancer Research judged that the evidence that physical activity protects against colorectal cancer was convincing, and the evidence that foods containing dietary fibre, garlic, milk and calcium protect against colorectal cancer was probable. On the other hand, the evidence that red meat, processed meat, alcoholic drinks for men, body fatness, abdominal fatness and adult attained height caused colorectal cancer was convincing, and the evidence that alcoholic drinks in women caused this cancer was probable.

Table 1 shows the positive and negative results on colorectal cancer protection of foods and nutrition.

\subsubsection{Foods judged to "probably" reduce the risk of colorectal cancer}

The 4 foods that affected the judgement that the evidence on the reduction of the risk of colorectal cancer was probable were food containing dietary fibre, garlic, milk and calcium.

\subsubsection{Dietary fibre}

Dietary fibre was associated with a reduced risk of colon cancer (Mastromarino et al., 1976). A meta-analysis of eight studies of dietary fibre estimated that the relative risk was 0.90 (95\% confidence interval (CI) 0.84-0.97) per $10 \mathrm{~g} /$ day increment (World Cancer Research Fund, 2007c).

A few negative results have been demonstrated. There was no association shown between dietary fibre consumption and the onset of colorectal cancer or adenoma by a 16-year follow-up prospective study (Fuchs et al., 1999). In the paper, a higher consumption of vegetable fibre was even associated with an increased risk of colorectal cancer in women. There was another negative result shown for dietary fibre, i.e., a high-fibre cereal supplement did not reduce recurrent colorectal adenomas (Alberts et al., 2000).

The mechanisms of the action of dietary fibre are not clearly elucidated yet, but it has been suggested that it dilutes faecal contents, decrease transit time, and increase stool weight (World Cancer Research Fund, 2007c, as cited in Cummings, 1981). Short-chain fatty acids, like butyrate, are produced by the gut flora from dietary carbohydrates that reach the colon, induce apoptosis and cell cycle arrest, and promote differentiation (World Cancer Research Fund, 2007c). Dietary fibre intake is important for lipid and glucose metabolism or for acting as prebiotics on microflora health in preventing colonic cancer (Donini et al., 2009). The consumption of fibre is associated to the consumption of folate (World Cancer Research Fund, 2007c), which has also been reported to be associated with a reduced risk of colorectal cancer (Sanjoaquin et al., 2005).

\subsubsection{Garlic}

In the "Global Perspective", the World Cancer Research Fund and American Institute for Cancer Research judged that garlic probably protects against colorectal cancer (World Cancer Research Fund, 2007c). Ally sulphur, which is considered to be an effective component of garlic, inhibited colon tumors in animal studies. The biologically active compounds derived from garlic have been proposed as allicin, diallyl sulphide (DAS), 


\begin{tabular}{|c|c|c|c|}
\hline $\begin{array}{l}\text { Food and } \\
\text { nutrition }\end{array}$ & Human studies & $\begin{array}{c}\text { RR }(95 \% \text { CI }) \\
\text { highest vs lowest } \\
\text { exposure when it is } \\
\text { not mentioned }\end{array}$ & ref. \\
\hline \multicolumn{4}{|c|}{$\begin{array}{l}\text { Foods containing dietary fibre } \\
\text { positive }\end{array}$} \\
\hline & $\begin{array}{l}\text { Dietary fibre was associated with a } \\
\text { reduced risk of recurrence of colorectal } \\
\text { adenomas in woman / meta-analysis } \\
\text { from } 8 \text { studies }\end{array}$ & $\begin{array}{l}0.90(0.84-0.97) \text { per } \\
10 \mathrm{~g} / \text { day increment }\end{array}$ & $\begin{array}{l}\text { World Cancer } \\
\text { Research } \\
\text { Fund, 2007c }\end{array}$ \\
\hline negative & $\begin{array}{l}\text { Dietary fibre was not associated with } \\
\text { colorectal cancer risk in women/16-year } \\
\text { follow-up cohort study }\end{array}$ & $0.95(0.73-1.25)$ & $\begin{array}{l}\text { Fuchs et al., } \\
1999\end{array}$ \\
\hline & $\begin{array}{l}\text { Dietary fibre from vegetable was } \\
\text { associated with an increased risk of } \\
\text { colorectal cancer in women/16-year } \\
\text { follow-up cohort study }\end{array}$ & $1.35(1.05-1.72)$ & $\begin{array}{l}\text { Fuchs et al., } \\
1999\end{array}$ \\
\hline & $\begin{array}{l}\text { Dietary supplement of wheat-bran fibre } \\
\text { was not associated a reduced risk of } \\
\text { recurrent colorectal } \\
\text { adenomas/randomized trial }\end{array}$ & $0.88(0.70-1.11)$ & $\begin{array}{l}\text { Alberts et al., } \\
2000\end{array}$ \\
\hline \multicolumn{4}{|l|}{$\begin{array}{l}\text { garlic } \\
\text { positive }\end{array}$} \\
\hline & $\begin{array}{l}\text { Garlic intake was probably associated } \\
\text { with a reduced risk of colon cancer } / 2 \\
\text { cohort studies and } 6 \text { case-control studies }\end{array}$ & $\begin{array}{l}0.77(0.51-1.16) \\
0.68(0.46-1.01)\end{array}$ & $\begin{array}{l}\text { World Cancer } \\
\text { Research } \\
\text { Fund, 2007c }\end{array}$ \\
\hline \multicolumn{4}{|l|}{$\begin{array}{l}\text { milk } \\
\text { positive }\end{array}$} \\
\hline & $\begin{array}{l}\text { Milk intake was associated with a } \\
\text { reduced risk of colorectal cancer/meta- } \\
\text { analysis from } 4 \text { cohort studies }\end{array}$ & $\begin{array}{l}0.94(0.85-1.03) \text { per } \\
\text { serving/day }\end{array}$ & $\begin{array}{l}\text { World Cancer } \\
\text { Research } \\
\text { Fund, 2007c }\end{array}$ \\
\hline & $\begin{array}{l}\text { Milk intake was associated with a } \\
\text { reduced risk of colorectal cancer/meta- } \\
\text { analysis from } 10 \text { cohort studies }\end{array}$ & $0.85(0.78-0.94)$ & $\begin{array}{l}\text { Cho et al., } \\
2004\end{array}$ \\
\hline & $\begin{array}{l}\text { Milk intake was associated with a } \\
\text { reduced risk of colorectal cancer/meta- } \\
\text { analysis from } 19 \text { cohort studies }\end{array}$ & $\begin{array}{l}0.91(0.85-0.94) \text { per } \\
200 \mathrm{~g} / \text { day of milk }\end{array}$ & $\begin{array}{l}\text { Aune et al., } \\
2011\end{array}$ \\
\hline \multicolumn{4}{|l|}{$\begin{array}{l}\text { calcium } \\
\text { positive }\end{array}$} \\
\hline & $\begin{array}{l}\text { Calcium supplementation was } \\
\text { associtated with a reduced risk of } \\
\text { adenomas/meta-analysis from } 2 \text { cohort } \\
\text { studies }\end{array}$ & $\begin{array}{l}0.95(0.92-0.98) \text { per } \\
200 \mathrm{mg} / \text { day }\end{array}$ & $\begin{array}{l}\text { World Cancer } \\
\text { Research } \\
\text { Fund, 2007c }\end{array}$ \\
\hline & $\begin{array}{l}\text { Total calcium intake and intake of } \\
\text { calcium from food sources was was } \\
\text { associtated with a reduced risk of } \\
\text { colorectal cancer/meta-analysis from } 10 \\
\text { cohort studies }\end{array}$ & $\begin{array}{l}0.78(0.69-0.88) \text { for } \\
\text { total calcium } \\
0.86(0.78-0.95) \text { for } \\
\text { calcium from food } \\
\text { sources }\end{array}$ & $\begin{array}{l}\text { World Cancer } \\
\text { Research } \\
\text { Fund, 2007c, } \\
\text { as cited in } \\
\text { Samad et al., } \\
2005\end{array}$ \\
\hline
\end{tabular}

Table 1. 
non-starchy vegetables and fruits

possitive

Conssumption of fruit was associated

with a reduced risk of colorecatl

cancer/meta-analysis from 8 cohort

studies

Conssumption of fruit was associated with a reduced risk of colorecatl cancer in women/meta-analysis from 5 cohort studies

Consumption of fruit was associtated with a reduced risk of colorectal cancer/cohort study

A high consumption of vegetable and fruit was association with a reduced risk of colorectal and colon cancer/cohort study

There is limited evidence suggesting that non-starchy vegetables protect against colorectal cancer

negative

Foods containing folate

Vegetarians diet was not significantly
associated with a reduced risk of
colorectal cancer/cohort study
A high consumption of vegetable was
not associated with recuded risk of rectal
cancer/cohort study
A high consumption of fruit was not
associated with recuded risk of colorectal
cancer/cohort study
positive

Dietary folate intake was associated with the recuced risk of colorectal cancer/meta-analysis of 7 cohort studies Total folate intake was associated with a recuced risk of colorectal cancer/metanalysis of 7 cohort studies

Selenium and foods containing selenium positive

Dietary selenium was associated with a reduced risk of colorectal cancer/A meta-analysis from 5 case-control studies

Fish

positive

Fish consumption was associated with a reduced risk of colorectal cancer/metaanalysis from 7 cohort studies
$0.97(0.92-1.03)$ per
serving/day

$0.81(0.85-0.98)$ per

serving/day

$0.57(0.34-0.97)$

$0.86(0.75-1.00)$ for colorectal cancer 0.76 (0.63-0.91) for colon cancer 1.00 (0.90-1.11) per 2 servings/day

0.85 (0.55-1.32) vegetarians vs nonvegetarians $0.92(0.79-1.06)$

$0.88(0.76-1.01)$

0.75 (0.64-0.89)

0.95 (0.81-1.11)

0.86 (0.78-0.95) per $10 \mu \mathrm{g} / \mathrm{dl}$ serum

0.96 (0.92-1.00) per serving/week
World Cancer

Research

Fund, 2007c

World Cancer

Research

Fund, 2007c

Sanjoaquin et al., 2004

van

Duijnhoven et al., 2009

World Cancer

Research

Fund, 2007c

Sanjoaquin et al., 2004

van

Duijnhoven et al., 2009

van

Duijnhoven et al., 2009

Sanjoaquin et al., 2005

Sanjoaquin et al., 2005

World Cancer

Research

Fund, 2007c

World Cancer

Research

Fund, 2007c

negative

Table 1. (continued) 
Consumption of salmon or cod was not associtated with local markers of inflammation, genotoxicity markers in colonocyte, and apoptotic and mitotic rate in colonic mucosa/randomized controlled study

Foods containing vitamin D

positive

Food containing vitamin D was associated with a reduced risk of colorectal cancer/meta-analysis from 9 cohort studies

Vitamins (except vitamin D) positive

A high consumption of vitamin C and E from both food and supplements (total) was associated with a reduced risk of colon cancer risk/pooled analysis of cohort studies

Multivitamin intake was associated with a reduced risk of colon cancer/pooled analysis of cohort studies

A high intake of either dietary nutrients (vitamin $\mathrm{C}$, vitamin $\mathrm{E}, \beta$-carotene, selenium, folate, vitamin B6, and vitamin B12) was associated a reduced the risk of distal colorectal cancer in the caucasian/case-control study

A high intake of dietary selenium was associated with a reduced risk of distal coloredtal cancer in African Americans/case-control study $\beta$-carotene intake was associated with a reduced risk of colorectal cancer in

negative men/cohort study

lycopene intake was associated with an increased risk of rectal cancer in men/cohort study

Pot et al., 2009;

Pot et al., 2010a; Pot et al., 2010b

$0.99(0.97-1.00)$ per $100 \mathrm{IU} /$ day

$0.80(0.71-0.90)$ for total vitamin C 0.82 (0.74-0.91) for total vitamin $\mathrm{E}$

$0.88(0.81-0.96)$

$0.58(0.42-0.80)$ for vitamin $\mathrm{C}$

0.65 (0.48-0.89) for vitamin $\mathrm{E}$ 0.52 (0.38-0.71) for $\beta$-carotene 0.55 (0.39-0.77) for selenium 0.50 (0.36-0.69) for folate 0.48 (0.35-0.67) for vitamin B6 0.59 (0.42-0.81) for vitamin B12 0.55 (0.29-1.02)

0.77 (0.763-0.95)

1.50 (1.04-2.16)
World Cancer

Research

Fund, 2007c

Park et al., 2010

Park et al., 2010

Williams et al., 2010

Williams et al., 2010

Park et al., 2009

Park et al., 2009

Table 1. (continued) 
Vitamin A, vitamin C, and vitamin E intake from food only were not associated with colon cancer risk / pooled analysis of cohort studies
A high consumption of carotenoid (except for $\beta$-carotene) was not associated with a reduced resk of colorecatl cancer/cohort study

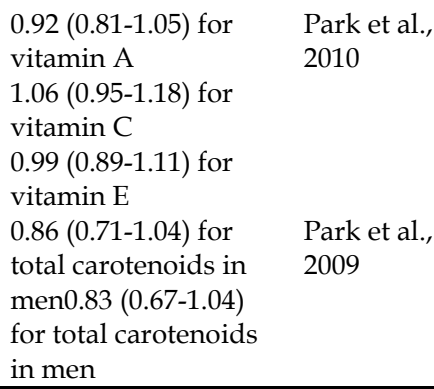

Abbreviations: RR, relative risk; 95\% CI, 95\% confidence interval

Table 1. Positive and negative result of food and nutrition on colorectal cancer protection.

diallyl disulphide (DADS), diallyl trisulfide (DATS) and ajoene. DAS, DADS and S-allylcysteie (SAC) demonstrated the inhibitory effect on colon cancer in the rat (Shukla \& Kalra, 2007).

In colon tumor cells, the induction of apoptosis, cell cycle modification and inhibition of tubulin polymerisation were suggested as the mechanism of the action of DATS, and the anti-proliferative effect, G2/M cell cycle arrest, decrease of polyamine biosynthesis, inhibition of histone deacetylase activity were suggested as the mechanisms of the actions of DADS (Filomeni et al., 2003; Shukla \& Kalra, 2007). It also has been reported that garlic and its constituents inhibit DNA adduct formation, scavenge free radicals and modulate Pglycoprotein-mediated multidrug resistance (Shukla \& Kalra, 2007).

\subsubsection{Milk and other dairy products}

A meta-analysis of "a global perspective" produced a summary effect estimate for relative risk of 0.94 (95\% CI 0.850-1.03) per serving/day (World Cancer Research Fund, 2007c). An analysis of data obtained from 10 cohort studies demonstrated that higher milk intake $\geqq$ $250 \mathrm{~g} /$ day) was related to a statistically significant reduced risk of colorectal cancer with relative risk 0.85 (95\% CI 0.78-0.94) compared with the lowest intake ( $<70 \mathrm{~g} /$ day) (Cho et al., 2004). According to the latest meta-analysis study, nineteen cohort studies concluded that the summary relative risk was 0.91 (95\% CI 0.85-0.94) per $200 \mathrm{~g} /$ day of milk, and 0.83 (95\% CI 0.78-0.88) per $400 \mathrm{~g} /$ day of total dairy products intake. There was no significant association between the consumption of cheese and a reduced risk (Aune et al., 2011).

Dietary milk fat globule membrane reduced the incidence of aberrant crypt foci in Fisher344 rats (Snow et al., 2010).

The cancer prevention effect of milk and dairy products is at least partly associated with the intake of calcium, which may bind to bile acids and ionized fatty acids to reduce cell proliferation and promote cell differentiation (Aune et al., 2011).

\subsubsection{Calcium (supplemented at a dose of $1200 \mathrm{mg} / \mathrm{day}$ )}

The main dietary sources of calcium in Europe and America are milk and dairy products. The meta-analysis estimate for the summary effect for colon cancer was 0.95 (95\% CI $0.92-$ 0.98) per $200 \mathrm{mg} /$ day of dietary calcium (World Cancer Research Fund, 2007c). Analysis from 10 cohort studies demonstrated that the total calcium had a greater correlation (relative risk 0.78 ; 95\% CI 0.69-0.88) to colorectal cancer than calcium from food sources (relative risk 0.86; 95\% CI 0.78-0.95) (World Cancer Research Fund, 2007c, as cited in Samad et al., 2005). 
On the other hand, there was a negative report regarding the chemoprevention effects of calcium, $2.5 \mathrm{~g} / \mathrm{kg}$ calcium reduced the number of small intestinal tumors, but increased the number of colon tumors (Huerta et al., 2003).

Calcium binds bile acids in the bowel lumen to inhibit their proliferative and carcinogenic effects, since bile acids might promote hyper-proliferation of the colorectal epithelium and carcinogenesis. Calcium may also act directly on the colonic epithelial cells to inhibit ras mutation (Bautista et al., 1997; Janne \& Mayer, 2000). Extracellular dietary calcium is associated with the activation of calcium-sensing receptors in intestinal epithelial cells, and then the activation of intracellular signalling pathways, including proliferation, differentiation, and apoptosis (Lamprecht \& Lipkin, 2001).

\subsubsection{Food judged to be "limited-suggestively" reduced cancer risk}

Since there was not sufficient evidence to judge, the factors below were concluded as limited-suggestive; non-starchy vegetables (not including salted and/or pickled products), fruits, foods containing folate, foods containing selenium, fish, foods containing vitamin D, and selenium (supplements at the dose of $1200 \mathrm{mg} /$ day).

\subsubsection{Fruit and vegetable}

It is quite complicated to investigate which nutrient has the most effective properties for colorectal cancer prevention, since non-starchy vegetables are a source of dietary fibre, carotenoids, folate, selenium, glucosinolates, and so on, and fruits are sources of vitamin C, carotenoids, phenols, flavonoids and other anti-oxidants. The results of the anti-cancer effects of fruit and vegetable are heterogeneous.

Dietary cruciferous vegetable intake was associated with a reduced colon risk of approximately 25\% (Marshall, 2008), There was an inverse association between the consumption of fruits and the risk of colorectal cancer, although the vegetarians showed a moderate, but non-significant, decrease in the risk (Sanjoaquin et al., 2004). A high consumption of vegetable and fruit showed an inverse association with colorectal and colon cancer, but not rectal cancer in the European Prospective Investigation into Cancer and Nutrition (EPIC). There was no significant inverse association shown between vegetable consumption or fruit consumption and colorectal, colon, or rectal cancer (Key et al., 2009; van Duijnhoven et al., 2009).

Vegetable-fruit mixture intake did not decrease the number of colon polyps both in low in fat $(20 \%$ of energy) and high in fat (40\% of energy) in the Apc Min mice which are genetically predisposed to intestinal polyps (van Kranen et al., 1998).

It has been reported that several fruits have a specific potency for cancer prevention. Apple is rich in quercetin (World Cancer Research Fund, 2007c). Apple juice also showed the potency of preventing colon carcinogenesis in mice, but this effect was not found under the cancer promoting conditions associated with obesity (Koch et al., 2009). On the other hand, Nandir et al. showed apple pomace increased the number and diameter of colon polyps in $A p c^{\mathrm{Min}}$ mice (Mandir et al., 2008). Citrus fruits are sources of antioxidants, such as vitamin C, phenols, flavonoid and bioactive phytochemicals. Vitamin $C$ traps free radicals and reactive oxygen species, and protects DNA from mutagenic damage (World Cancer Research Fund, 2007c). Cruciferous vegetables, such as broccoli, cabbage and cauliflower, reduced the colorectal cancer risk (Marshall, 2008), although there was also a negative report (Graham et al., 1988). 


\subsubsection{Foods containing folate and folate}

According to the meta-analysis study, there was strong association between folate consumption and colorectal cancer risk in 7 cohort studies. Dietary folate showed a stronger association (relative risk for high vs. low intake $=0.75$; 95\% CI 0.64-0.89) than total folate (relative risk for high vs. low $=0.95 ; 95 \%$ CI 0.81-1.11) (Sanjoaquin et al., 2005). Folate intake was strongly correlated with dietary fibre intake (World Cancer Research Fund, 2007c).

Animal studies also supported the cancer prevention properties of folate, however, intervention with exceptionally high doses of folate (2.0-5.0 $\mathrm{g}$ of folic acid/ $\mathrm{kg}$ diet) after the formation of microscopic neoplastic foci may have promoted colorectal carcinogenesis (Kim, 2003). Folate reduced the number of small intestinal tumors in mice, although the timing of folate intervention was critical in preventive properties. In contrast, this effect was not found in colon (Song et al., 2000).

Folate deficiency has the potential to modulate DNA synthesis, DNA methylation, DNA damage and impaired DNA repair, increase mutagenesis, hyperproliferation, abnormal apoptosis, and methylenetetrahydrofolate reductase (MTHFR) polymorphisms and related gene-nutrient interactions (Prinz-Langenohl et al., 2001; Kim, 2003).

Under certain conditions, folate potentialy has an inverse effect on cancer prevention. In DNA polymerase $\beta$ deficiency mice, folate deficiency provided protection against tumorigenesis, the induction of apoptosis, and the suppression of cell proliferation (Ventrella-Lucente et al., 2010)

\subsubsection{Selenium and foods containing selenium}

A meta-analysis of "a global perspective" produced a summary effect estimate of 0.86 (95\% CI 0.78-0.95) per $10 \mu \mathrm{g} / \mathrm{dl}$ serum, with high heterogeneity (World Cancer Research Fund, 2007c). Dietary selenium deficiency has been reported to cause a lack of selenoprotein expression, and some of these selenoproteins play important roles in anti-inflammatory and antioxidant properties (Ganther, 1999).

Selenium-enriched broccoli reduced the number of small intestinal tumors in multiple intestinal neoplasia mice (Davis et al., 2002). In the study, selenium-enriched diet for 10 weeks significantly increased the plasma concentration of selenium, and reduced small intestinal ( $46.3 \pm 3.7$ vs $65.6 \pm 6.1)$ and large intestin $(0.43 \pm 3.7$ vs $1.93 \pm 6.1)$ tumors than control diet.

Several mechanisms have been suggested for the cancer preventiion effect of selenium, including the induction of apoptosis, cell cycle modulation (inhibition of cdk2 and protein kinase C), and the activation of thioredoxin redactase (Combs, 2004).

\subsubsection{Fish}

A meta-analysis of "a global perspective" produced a summary effect estimate of 0.96 (95\% CI 0.92-1.00) per serving/week. A high consumption of fish is associated with low consumption of meat (World Cancer Research Fund, 2007c).

Increasing salmon or cod consumption for 6 months resulted in a lower concentration of the systemic inflammation marker C-reactive protein (CRP), but showed no effect on the local 
markers of inflammation in the colonic biopsies or feces, the genotoxicity markers in colonocyte, and apoptotic and mitotic rate in colonic mucosa (Pot et al., 2009; Pot et al., 2010a; Pot et al., 2010b).

An animal study showed that fish oil significantly reduced colon tumors (Rao et al., 2001). A diet including fish oil and pectin protects against colon cancer, compared with that of corn oil and cellulose azoxymethane, which induced colon cancer in model rats (Cho et al., 2011).

The preventive mechanisms of fish have been proposed to include the effects on gene expression, decreasing adhesion genes such as B44galt1 at the initiation stage, lowering the expression of both cell promoters and suppressors at the aberrant crypt foci (ACF) stage, and increasing apoptosis inducing genes at the tumor stage. These modifications may be associated to the induction of apoptosis and the suppression of proliferation (Cho et al., 2011). Fish n-3 polyunsaturated fatty acids (PUFAs) may reduce eicosanoid biosynthesis derived from n-6 PUFA to protect tissue from inflammation, and inhibit COX-2 (Rao et al., 2001).

On the other hand, it has been reported that dietary fish oil containing docosahexaenoic acid (DHA) promotes inflammation through the modification of CD4+ and CD8+ T-cell populations in SMAD-/- mice and that chronic inflammation is the risk factor for colorectal cancer (Woodworth et al., 2010).

\subsubsection{Foods containing vitamin D}

A meta-analysis of "a global perspective" produced a summary effect estimate of 0.99 (95\% CI 0.97-1.00) per 100 IU/day (World Cancer Research Fund, 2007c). Higher vitamin D levels are associated with a lower risk of colon cancer and overall mortality. UV exposure stimulates vitamin D production, but it may increase the risk of skin cancer. Therefore it is recommended that high-risk populations with a low level of vitamin D intake increase the consumption of fish, or take vitamin D supplements (Zeeb \& Greinert, 2010).

Vitamin D induces differentiation, apoptosis and induces G1 phase arrest in intestinal cells. It also increases the absorption of calcium in the small and large intestine. Most of the pleiotropic, long-term actions of $\left[1,25(\mathrm{OH})_{2} \mathrm{D}_{3}\right]$ are mediated by binding to vitamin $\mathrm{D}$ receptors (VDR), which are high-affinity receptors in the nucleus of cells. Activated VDR induces gene transcription, and VDR density in colonic mucosa was higher in hyperplastic polyps and in early stages of carcinogenesis, compared with normal mucosa (Lamprecht \& Lipkin, 2001; Lamprecht \& Lipkin, 2003; World Cancer Research Fund, 2007c).

\subsubsection{Limited-non conclusive and others}

There was not enough evidence for cancer prevention at the time of when "a grovel Perspective" was drawn up in 2007, so the following foods and nutrition were judged limited-non conclusive: Cereals (grains) and their products, potatoes, poultry, shellfish and other seafood, other dairy products, total fat, fatty acid, cholesterol, sugar (sucrose), coffee, tea, caffeine, total carbohydrate, starch, vitamin A, retinol, vitamin C, vitamin E, multivitamins, non-dairy sources of calcium, methionine, beta-carotene, alpha-carotene, lycopene, meal frequency, and energy intake.

Some of the latest research has demonstrated new knowledge, or confirmed the previous results. 


\subsubsection{Vitamins (except vitamin D)}

A pooled analysis of cohort studies concluded that a high consumption of vitamin $\mathrm{C}$ and $\mathrm{E}$ from both food and supplements showed an inverse association with colon cancer risk, although there were some interactions with folate intake. Multivitamin intake also significantly decreases the risk of colon cancer. On the other hand, vitamin A, vitamin C, and vitamin $\mathrm{E}$ intake from food only were not associated with colon cancer risk (Park et al., 2010).

In the Caucasian race, a high intake of each anti-oxidant nutrient (vitamin $C$, vitamin $E, \beta$ carotene, selenium) and DNA methylation-related nutrients (folate, vitamin B6, vitamin B12) reduced the risk of distal colorectal cancer, and only selenium showed a lower risk in African Americans. In this study, both intake from food only and total intake (food and supplements) demonstrated cancer prevention potency (Williams et al., 2010).

In colorectal cancer patients, the level of vitamin A, vitamin C, and vitamin E were reduced, and urinary 8-oxo-dG, a biomarker of DNA oxidation, was elevated (Obtulowicz et al., 2010).

A high consumption of carotenoid did not reduce the risk of colorectal cancer, except for $\beta$ carotene intake among men, which showed an inverse association (relative risk $0.77,95 \% \mathrm{CI}$ $0.763-0.95)$. On the other hand, lycopene intake was significantly associated with an increase in the risk of rectal cancer among men (relative risk 1.50, 95\% CI 1.04-2.16) (Park et al., 2009).

\subsubsection{Other dietary factors}

Avenanthraide (Avns) polyphenols from oats showed anti-proliferative effects independent of Cox-2 expression in COX-2 positive HT29, Caco-2 and LS174T cells, and COX-2 negative HCT116 cells. Avns may also reduce the colon cancer risk inhibiting PGE2 production derived from macrophage (Guo et al., 2010).

In animal studies, the oral administration of flavone $(400 \mathrm{mg} / \mathrm{kg}$ over 4 weeks) increased apoptosis and reduced the rate of aberrant crypt formation in mice. The down-regulation of the tricarboxylic acid cycle may be a part of the action mechanism (Winkelmann et al., 2010). In a human study, a case-control study of dietary flavonoid showed that flavonoid, especially quercetin, was significantly associated with a reduction in the colorectal cancer risk (Kyle et al., 2010).

In an SD rat study, Coenzyme Q10 reduced the number of APFs, possibly by modulating COX-2 and iNOS gene expression in colonic mucosa, and DNA damage in leukocytes (Kim \& Park, 2010).

It has been reported that an increased consumption of n-3 fatty acid, Sulforaphane, Chafuroside, Curcumin and Dibenzoylmethane decreased the number of small intestinal tumors in $A p c^{\mathrm{Min}}$ mice. On the other hand, there are a few reports on colonic tumor that showed that $31 \mathrm{~g} / \mathrm{kg}$ of steridonic acid or $600 \mathrm{ppm}$ of sulforaphane demonstrated an inhibitory effect on colonic tumors in $A p c^{\text {Min }}$ mice (Petrik et al., 2000; Shen et al., 2007).

\subsection{The latest proposed action mechanisms}

Various mechanisms, such as DNA repair, proapoptosis, cell cycle modification, immunity promotion, and the mediation of chemomediators, have been proposed as the effects of 
foods and nutrition. Recently, the focus has been on the prebiotic and probiotic effects, insulin-like growth factor (IGF) regulation, and calorie restriction.

\subsubsection{Prebiotic and probiotic effects}

Feeding specific food products with a prebiotic effect have been reported to reduce the incidence of tumors and cancers (Roberfroid et al., 2010). There are 100 trillion microbial organisms, called the microbiota, in human adult gut (Davis \& Milner, 2009). Carbohydrate and proteolytic fermentation are the two main types of anaerobic fermentation in the gastrointestinal tract (Davis \& Milner, 2009, as cited in (McIntosh et al., 1999).

Prebiotics are non-digestible food ingredients which stimulate beneficial gut microbiota (Lim et al., 2005), e.g. inulin and other oligosaccharides, lactulose and resistant starch, such as fructooligosaccharides, inulin, lactulose and galactooligosaccharides (Tuohy et al., 2005). Probiotics are live bacteria found in processed foods or in dietary supplements, e.g. yogurt, cheese, fermented milks, juices, smoothies, cereal, and nutrition bars (Penner et al., 2005; Davis \& Milner, 2009). Synbiotics are a combination of a probiotic with a prebiotic. A prebiotic can support the activity of a probiotic (Gibson \& Roberfroid, 1995).

Prebiotics must survive acidic conditions in the stomach and resist digestion in the small intestine. Then they need to be selectively fermented, and stimulate beneficial bacteria, usually bifidobacteria or lactobacilli, in the colon (Tuohy et al., 2005). In the randomized, double-blind, placebo-controlled trial for 12 weeks, dietary synbiotics reduced colon cancer risk, through increasing Bifidobacterium and Lactobacillus, and decreasing Clostridium perfringens (Rafter et al., 2007).

A 4-year supplementation regime employing Lactobacillus casei decreased the recurrence of atypical colonic polyps (Ishikawa et al., 2005).

Several animal studies and human trials showed that prebiotics, probiotics and synbiotics reduced toxic metabolite production, like caecal $\beta$-glucuronidase, nitrate reductase activities and caecal $\mathrm{pH}$, in the gut, resulting in the prevention of colorectal cancer. On the other hand, some human studies denied the beneficial effects of prebiotics (Tuohy et al., 2005).

An increased number of bifidobacteria and/or lactobacilli may also play an important role in DNA protective modification and chemically-induced DNA damage (Tuohy et al., 2005). An increased number of biofidobacteria and/or lactobacilli in the gut may suppress the number or activity of putative enteropathogens such as Escherichia coli and Clostridium perfingens (Reddy, 1999). Prebiotics may also stimulate protective enzyme activities within the intestinal mucosa or reduce the immune inflammatory response (Burns \& Rowland, 2000).

Since prebiotics are mostly oligosaccharides, it is considered that they reduce blood glucose. Increasing glycosylated hemogloin (HbA1c), which is a biomarker of glucose control for diabetes, was associated with an increased risk of colorectal cancer in women (Chan \& Giovannucci, 2010). However, the consumption of short-chain fructooligosaccharides did not have a significant affect on the glucose level in blood (Luo et al., 2000).

Transplantation of the gut microflora from normal mice into germ-free recipients resulted in increasing their body fat without increasing food consumption (Bajzer \& Seeley, 2006). A 1- 
year low calorie diet in obese people modified the proportion of gut microbes, increasing bacteroidestes and decreasing firmicutes, while obese people had fewer bacteroidetes and firmicutes, compared with a lean control group (Ley et al., 2006).

Supplementation employing a drink fortified with short-chain fructooligosaccharides and inulin (1.5 g/day) significantly increased the absorption of calcium in adolescent girls (Griffin et al., 2002). The consumption of oligosaccharides also improved the magnesium absorption in humans and animals (Coudray et al., 2003). An optimum well-tolerated dose of prebiotics might be $10 \mathrm{~g} /$ day and a high dose (e.g. $>20 \mathrm{~g} /$ day) of some prebiotics might have a laxation effect, such as stool frequency or stool weight (Bouhnik et al., 1999).

\subsubsection{IGF regulation}

IGF play important roles in proliferation, differentiation and transfomation in a variety of cell types, and thus it has been suggested that dysregulation of the IGF is an important cancer risk factor (Park, 2008).

A study on colon adenocarcinoma showed that n-3 polyunsaturated fatty acids, eicosapentaenoic acid (EPA) and docosahexaenoic acid (DHA), increased IGFBP-6 in human colon adenocarcinoma Caco- 2 cells, and the authors proposed that low IGF-II/IGFBP-6 ratios have resulted in less free IGF-II and a resulting slower proliferation of Caco-2 cells (Roynette et al., 2004). All-trans retinoic acid (tRA) showed an anti-proliferative effect in Caos-2 cells, and it was considered that this was due to a partly increased IGFBP-6 expression (Kim et al., 2002).

A low-calcemic vitamin D analogus decreased the secretion of IGF-II and suppressed HT-29 cell proliferation (Oh et al., 2001).

\subsubsection{Calorie restriction}

Calorie restriction in $A p c^{\text {Min }}$ mice at the rate of $40 \%$ reduced the number of intestinal polyps by $57 \%$, compared with mice fed ad libium. The serum levels of IGF-1 and leptin, and urinary corticosterone output were significantly reduced in the calorie restriction group, compared with that of the ad libium group. Supplementation of freeze-dried fruit and vegetable extract with a diet high in olive oil also reduced the number of polyps, even though this group had a calorie intake of about $90 \%$ of ad libium. The supplementation of fruit and vegetables significantly reduced the urinary corticosterone output levels, but did not show any effect on the serum levels of IGF-1 and leptin (Mai et al., 2003).

These results indicate that calorie restriction has a great potency for colon cancer prevention, and a diet in high fruit and vegetable without calorie restriction showed less, but still significant, intestinal tumorigenesis preventive effects.

Calorie restriction or increased exposure to n-3 fatty acid, sulforaphe, chafrroside, curcumin and dibenzoylmethane reduced the risk of colon cancer, while total fat, a diet high in calories and all-trans retinoic acid increased the risk (Tammariello \& Milner, 2010).

However, even considering these interesting results, the frequency of colon polyps in the calorie restriction group and the fruit and vegetable group did not show any significant changes, compared with the ad libium group (van Kranen et al., 1998). 


\section{Conclusion}

The contribution of diet in all cancer-related death estimates was $30-35 \%$ in the environmental factors, greater than tobacco, which was $25-30 \%$. Colorectal cancer was strongly associated with diet, and linked to $70 \%$ of cancer related-deaths (Anand et al., 2008). Eating habits are the most important factor for colorectal cancer prevention, however, it is still difficult to specify how we should eat. It has been proposed that an increase in the consumption of fruit and vegetables and less intake of red and processed meat will comprise a better diet. However, it has not been proven yet how much of a respective increase and decrease is the best quantity, and which nutrients exactly play a key role in carcinogenesis and anti-carcinogenesis. Plenty of studies have been published on food components or nutrients to protect from carcinogenesis in vitro, describing the molecular action mechanisms involved. In human trials, individual nutrients, such as supplements, often showed no or less intended function, while nutrients contained in food functioned as expected. Accordingly, the judgement from a global perspective concluded that it was not appropriate to recommend the usage of supplements for cancer prevention at the present (World Cancer Research Fund, 2007d). The ideal diet for cancer prevention may be a wellbalanced diet, and no one food or ingredient should be considered a miracle food. Further studies are required to elucidate precisely the disposition and safety of nutrients and the interaction of each nutrient.

\section{References}

Adegboyega, P.A.; Ololade, O.; Saada, J.; Mifflin, R.; Di Mari, J.F. \& Powell, D.W. (2004). Subepithelial myofibroblasts express cyclooxygenase-2 in colorectal tubular adenomas. Clin Cancer Res, Vol. 10, No. 17, pp. 5870-5879, ISSN 1078-0432

Alberts, D.S.; Martinez, M.E.; Roe, D.J.; Guillen-Rodriguez, J.M.; Marshall, J.R.; van Leeuwen, J.B.; Reid, M.E.; Ritenbaugh, C.; Vargas, P.A.; Bhattacharyya, A.B.; Earnest, D.L. \& Sampliner, R.E. (2000). Lack of effect of a high-fiber cereal supplement on the recurrence of colorectal adenomas. Phoenix Colon Cancer Prevention Physicians' Network. N Engl J Med, Vol. 342, No. 16, pp. 1156-1162, ISSN 0028-4793

Anand, P.; Kunnumakkara, A.B.; Sundaram, C.; Harikumar, K.B.; Tharakan, S.T.; Lai, O.S.; Sung, B. \& Aggarwal, B.B. (2008). Cancer is a preventable disease that requires major lifestyle changes. Pharm Res, Vol. 25, No. 9, pp. 2097-2116, ISSN 0724-8741

Aune, D.; Lau, R.; Chan, D.S.; Vieira, R.; Greenwood, D.C.; Kampman, E. \& Norat, T. (2011). Dairy products and colorectal cancer risk: a systematic review and meta-analysis of cohort studies. Ann Oncol, Vol. No., ISSN 1569-8041

Bajzer, M. \& Seeley, R.J. (2006). Physiology: obesity and gut flora. Nature, Vol. 444, No. 7122, pp. 1009-1010, ISSN 1476-4687

Bautista, D.; Obrador, A.; Moreno, V.; Cabeza, E.; Canet, R.; Benito, E.; Bosch, X. \& Costa, J. (1997). Ki-ras mutation modifies the protective effect of dietary monounsaturated fat and calcium on sporadic colorectal cancer. Cancer Epidemiol Biomarkers Prev, Vol. 6, No. 1, pp. 57-61, ISSN 1055-9965

Bouhnik, Y.; Vahedi, K.; Achour, L.; Attar, A.; Salfati, J.; Pochart, P.; Marteau, P.; Flourie, B.; Bornet, F. \& Rambaud, J.C. (1999). Short-chain fructo-oligosaccharide 
administration dose-dependently increases fecal bifidobacteria in healthy humans. J Nutr, Vol. 129, No. 1, pp. 113-116, ISSN 0022-3166

Boursi, B. \& Arber, N. (2007). Current and future clinical strategies in colon cancer prevention and the emerging role of chemoprevention. Curr Pharm Des, Vol. 13, No. 22, pp. 2274-2282, ISSN 1873-4286

Burns, A.J. \& Rowland, I.R. (2000). Anti-carcinogenicity of probiotics and prebiotics. Curr Issues Intest Microbiol, Vol. 1, No. 1, pp. 13-24, ISSN 1466-531X

Cadet, J.; Douki, T. \& Ravanat, J.L. (2010). Oxidatively generated base damage to cellular DNA. Free Radic Biol Med, Vol. 49, No. 1, pp. 9-21, ISSN 1873-4596

Chan, A.T. \& Giovannucci, E.L. (2010). Primary prevention of colorectal cancer. Gastroenterology, Vol. 138, No. 6, pp. 2029-2043 e2010, ISSN 1528-0012

Cho, E.; Smith-Warner, S.A.; Spiegelman, D.; Beeson, W.L.; van den Brandt, P.A.; Colditz, G.A.; Folsom, A.R.; Fraser, G.E.; Freudenheim, J.L.; Giovannucci, E.; Goldbohm, R.A.; Graham, S.; Miller, A.B.; Pietinen, P.; Potter, J.D.; Rohan, T.E.; Terry, P.; Toniolo, P.; Virtanen, M.J.; Willett, W.C.; Wolk, A.; Wu, K.; Yaun, S.S.; ZeleniuchJacquotte, A. \& Hunter, D.J. (2004). Dairy foods, calcium, and colorectal cancer: a pooled analysis of 10 cohort studies. J Natl Cancer Inst, Vol. 96, No. 13, pp. 10151022, ISSN 1460-2105

Cho, Y.; Kim, H.; Turner, N.D.; Mann, J.C.; Wei, J.; Taddeo, S.S.; Davidson, L.A.; Wang, N.; Vannucci, M.; Carroll, R.J.; Chapkin, R.S. \& Lupton, J.R. (2011). A chemoprotective fish oil- and pectin-containing diet temporally alters gene expression profiles in exfoliated rat colonocytes throughout oncogenesis. J Nutr, Vol. 141, No. 6, pp. 10291035, ISSN 1541-6100

Combs, G.F., Jr. (2004). Status of selenium in prostate cancer prevention. Br J Cancer, Vol. 91, No. 2, pp. 195-199, ISSN 0007-0920

Cottet, V.; Bonithon-Kopp, C.; Kronborg, O.; Santos, L.; Andreatta, R.; Boutron-Ruault, M.C. \& Faivre, J. (2005). Dietary patterns and the risk of colorectal adenoma recurrence in a European intervention trial. Eur J Cancer Prev, Vol. 14, No. 1, pp. 21-29, ISSN 0959-8278

Coudray, C.; Demigne, C. \& Rayssiguier, Y. (2003). Effects of dietary fibers on magnesium absorption in animals and humans. J Nutr, Vol. 133, No. 1, pp. 1-4, 0022-3166

Cummings, J.H. (1981). Dietary fibre and large bowel cancer. Proc Nutr Soc, Vol. 40, No. 1, pp. 7-14, ISSN 0029-6651

Davis, C.D. \& Milner, J.A. (2009). Gastrointestinal microflora, food components and colon cancer prevention. J Nutr Biochem, Vol. 20, No. 10, pp. 743-752, ISSN 1873-4847

Davis, C.D.; Zeng, H. \& Finley, J.W. (2002). Selenium-enriched broccoli decreases intestinal tumorigenesis in multiple intestinal neoplasia mice. J Nutr, Vol. 132, No. 2, pp. 307309, ISSN 0022-3166

Dixon, L.B.; Balder, H.F.; Virtanen, M.J.; Rashidkhani, B.; Mannisto, S.; Krogh, V.; van Den Brandt, P.A.; Hartman, A.M.; Pietinen, P.; Tan, F.; Virtamo, J.; Wolk, A. \& Goldbohm, R.A. (2004). Dietary patterns associated with colon and rectal cancer: results from the Dietary Patterns and Cancer (DIETSCAN) Project. Am J Clin Nutr, Vol. 80, No. 4, pp. 1003-1011, ISSN 0002-9165 
Donini, L.M.; Savina, C. \& Cannella, C. (2009). Nutrition in the elderly: role of fiber. Arch Gerontol Geriatr, Vol. 49 Suppl 1, No., pp. 61-69, ISSN 1872-6976

Fearon, E.R. \& Vogelstein, B. (1990). A genetic model for colorectal tumorigenesis. Cell, Vol. 61, No. 5, pp. 759-767, ISSN 0092-8674

Filomeni, G.; Aquilano, K.; Rotilio, G. \& Ciriolo, M.R. (2003). Reactive oxygen speciesdependent c-Jun NH2-terminal kinase/c-Jun signaling cascade mediates neuroblastoma cell death induced by diallyl disulfide. Cancer Res, Vol. 63, No. 18, pp. 5940-5949, ISSN 0008-5472

Fuchs, C.S.; Giovannucci, E.L.; Colditz, G.A.; Hunter, D.J.; Stampfer, M.J.; Rosner, B.; Speizer, F.E. \& Willett, W.C. (1999). Dietary fiber and the risk of colorectal cancer and adenoma in women. N Engl J Med, Vol. 340, No. 3, pp. 169-176, ISSN 0028-4793

Ganther, H.E. (1999). Selenium metabolism, selenoproteins and mechanisms of cancer prevention: complexities with thioredoxin reductase. Carcinogenesis, Vol. 20, No. 9, pp. 1657-1666, ISSN 0143-3334

Gibson, G.R. \& Roberfroid, M.B. (1995). Dietary modulation of the human colonic microbiota: introducing the concept of prebiotics. J Nutr, Vol. 125, No. 6, pp. 14011412, ISSN 0022-3166

Graham, S.; Marshall, J.; Haughey, B.; Mittelman, A.; Swanson, M.; Zielezny, M.; Byers, T.; Wilkinson, G. \& West, D. (1988). Dietary epidemiology of cancer of the colon in western New York. Am J Epidemiol, Vol. 128, No. 3, pp. 490-503, ISSN 0002-9262

Griffin, I.J.; Davila, P.M. \& Abrams, S.A. (2002). Non-digestible oligosaccharides and calcium absorption in girls with adequate calcium intakes. Br J Nutr, Vol. 87 Suppl 2, No., pp. S187-191, ISSN 0007-1145

Guo, W.; Nie, L.; Wu, D.; Wise, M.L.; Collins, F.W.; Meydani, S.N. \& Meydani, M. (2010). Avenanthramides inhibit proliferation of human colon cancer cell lines in vitro. Nutr Cancer, Vol. 62, No. 8, pp. 1007-1016, ISSN 1532-7914

Huerta, S.; Irwin, R.W.; Heber, D.; Go, V.L.; Moatamed, F.; Ou, C. \& Harris, D.M. (2003). Intestinal polyp formation in the Apcmin mouse: effects of levels of dietary calcium and altered vitamin D homeostasis. Dig Dis Sci, Vol. 48, No. 5, pp. 870-876, ISSN 0163-2116

Ishikawa, H.; Akedo, I.; Otani, T.; Suzuki, T.; Nakamura, T.; Takeyama, I.; Ishiguro, S.; Miyaoka, E.; Sobue, T. \& Kakizoe, T. (2005). Randomized trial of dietary fiber and Lactobacillus casei administration for prevention of colorectal tumors. Int J Cancer, Vol. 116, No. 5, pp. 762-767, ISSN 0020-7136

Janne, P.A. \& Mayer, R.J. (2000). Chemoprevention of colorectal cancer. N Engl J Med, Vol. 342, No. 26, pp. 1960-1968, ISSN 0028-4793

Jemal, A.; Bray, F.; Center, M.M.; Ferlay, J.; Ward, E. \& Forman, D. (2011). Global cancer statistics. CA Cancer J Clin, Vol. 61, No. 2, pp. 69-90, ISSN 1542-4863

Key, T.J.; Appleby, P.N.; Spencer, E.A.; Travis, R.C.; Roddam, A.W. \& Allen, N.E. (2009). Mortality in British vegetarians: results from the European Prospective Investigation into Cancer and Nutrition (EPIC-Oxford). Am J Clin Nutr, Vol. 89, No. 5, pp. 1613S-1619S, ISSN 1938-3207 
Key, T.J.; Thorogood, M.; Appleby, P.N. \& Burr, M.L. (1996). Dietary habits and mortality in 11,000 vegetarians and health conscious people: results of a 17 year follow up. BMJ, Vol. 313, No. 7060, pp. 775-779, ISSN 0959-8138

Kim, E.J.; Schaffer, B.S.; Kang, Y.H.; Macdonald, R.G. \& Park, J.H. (2002). Decreased production of insulin-like growth factor-binding protein (IGFBP)-6 by transfection of colon cancer cells with an antisense IGFBP-6 cDNA construct leads to stimulation of cell proliferation. J Gastroenterol Hepatol, Vol. 17, No. 5, pp. 563-570, ISSN 0815-9319

Kim, J.M. \& Park, E. (2010). Coenzyme Q10 attenuated DMH-induced precancerous lesions in SD rats. J Nutr Sci Vitaminol (Tokyo), Vol. 56, No. 2, pp. 139-144, ISSN 1881-7742

Kim, M.K.; Sasaki, S.; Otani, T. \& Tsugane, S. (2005). Dietary patterns and subsequent colorectal cancer risk by subsite: a prospective cohort study. Int J Cancer, Vol. 115, No. 5, pp. 790-798, ISSN 0020-7136

Kim, Y.I. (2003). Role of folate in colon cancer development and progression. J Nutr, Vol. 133, No. 11 Suppl 1, pp. 3731S-3739S, ISSN 0022-3166

Ko, S.C.; Chapple, K.S.; Hawcroft, G.; Coletta, P.L.; Markham, A.F. \& Hull, M.A. (2002). Paracrine cyclooxygenase-2-mediated signalling by macrophages promotes tumorigenic progression of intestinal epithelial cells. Oncogene, Vol. 21, No. 47, pp. 7175-7186, ISSN 0950-9232

Koch, T.C.; Briviba, K.; Watzl, B.; Fahndrich, C.; Bub, A.; Rechkemmer, G. \& Barth, S.W. (2009). Prevention of colon carcinogenesis by apple juice in vivo: impact of juice constituents and obesity. Mol Nutr Food Res, Vol. 53, No. 10, pp. 1289-1302, ISSN 1613-4133

Kryston, T.B.; Georgiev, A.B.; Pissis, P. \& Georgakilas, A.G. (2011). Role of oxidative stress and DNA damage in human carcinogenesis. Mutat Res, Vol. 711, No. 1-2, pp. 193201, ISSN 0027-5107

Kyle, J.A.; Sharp, L.; Little, J.; Duthie, G.G. \& McNeill, G. (2010). Dietary flavonoid intake and colorectal cancer: a case-control study. Br J Nutr, Vol. 103, No. 3, pp. 429-436, ISSN $1475-2662$

Lamprecht, S.A. \& Lipkin, M. (2001). Cellular mechanisms of calcium and vitamin D in the inhibition of colorectal carcinogenesis. Ann N Y Acad Sci, Vol. 952, No., pp. 73-87, ISSN 0077-8923

Lamprecht, S.A. \& Lipkin, M. (2003). Chemoprevention of colon cancer by calcium, vitamin D and folate: molecular mechanisms. Nat Rev Cancer, Vol. 3, No. 8, pp. 601-614, ISSN 1474-175X

Ley, R.E.; Turnbaugh, P.J.; Klein, S. \& Gordon, J.I. (2006). Microbial ecology: human gut microbes associated with obesity. Nature, Vol. 444, No. 7122, pp. 1022-1023, ISSN $1476-4687$

Lim, C.C.; Ferguson, L.R. \& Tannock, G.W. (2005). Dietary fibres as "prebiotics": implications for colorectal cancer. Mol Nutr Food Res, Vol. 49, No. 6, pp. 609-619, ISSN 1613-4125

Luo, J.; Van Yperselle, M.; Rizkalla, S.W.; Rossi, F.; Bornet, F.R. \& Slama, G. (2000). Chronic consumption of short-chain fructooligosaccharides does not affect basal hepatic glucose production or insulin resistance in type 2 diabetics. J Nutr, Vol. 130, No. 6, pp. 1572-1577, ISSN 0022-3166 
Lynch, H.T. \& de la Chapelle, A. (2003). Hereditary colorectal cancer. N Engl J Med, Vol. 348, No. 10, pp. 919-932, ISSN 1533-4406

Mai, V.; Colbert, L.H.; Berrigan, D.; Perkins, S.N.; Pfeiffer, R.; Lavigne, J.A.; Lanza, E.; Haines, D.C.; Schatzkin, A. \& Hursting, S.D. (2003). Calorie restriction and diet composition modulate spontaneous intestinal tumorigenesis in Apc(Min) mice through different mechanisms. Cancer Res, Vol. 63, No. 8, pp. 1752-1755, ISSN 00085472

Mandir, N.; Englyst, H. \& Goodlad, R.A. (2008). Resistant carbohydrates stimulate cell proliferation and crypt fission in wild-type mice and in the $\mathrm{Apc}(\mathrm{Min} /+)$ mouse model of intestinal cancer, association with enhanced polyp development. $\mathrm{Br} \mathrm{J}$ Nutr, Vol. 100, No. 4, pp. 711-721, ISSN 1475-2662

Marshall, J.R. (2008). Prevention of colorectal cancer: diet, chemoprevention, and lifestyle. Gastroenterol Clin North Am, Vol. 37, No. 1, pp. 73-82, vi, ISSN 0889-8553

Martin, O.A.; Redon, C.E.; Nakamura, A.J.; Dickey, J.S.; Georgakilas, A.G. \& Bonner, W.M. (2011). Systemic DNA damage related to cancer. Cancer Res, Vol. 71, No. 10, pp. 3437-3441, ISSN 1538-7445

Martinez-Outschoorn, U.E.; Pavlides, S.; Howell, A.; Pestell, R.G.; Tanowitz, H.B.; Sotgia, F. \& Lisanti, M.P. (2011). Stromal-epithelial metabolic coupling in cancer: integrating autophagy and metabolism in the tumor microenvironment. Int J Biochem Cell Biol, Vol. 43, No. 7, pp. 1045-1051, ISSN 1878-5875

Mastromarino, A.; Reddy, B.S. \& Wynder, E.L. (1976). Metabolic epidemiology of colon cancer: enzymic activity of fecal flora. Am J Clin Nutr, Vol. 29, No. 12, pp. 1455-1460, ISSN 0002-9165

McIntosh, G.H.; Royle, P.J. \& Playne, M.J. (1999). A probiotic strain of L. acidophilus reduces DMH-induced large intestinal tumors in male Sprague-Dawley rats. Nutr Cancer, Vol. 35, No. 2, pp. 153-159, ISSN 0163-5581

Obtulowicz, T.; Swoboda, M.; Speina, E.; Gackowski, D.; Rozalski, R.; Siomek, A.; Janik, J.; Janowska, B.; Ciesla, J.M.; Jawien, A.; Banaszkiewicz, Z.; Guz, J.; Dziaman, T.; Szpila, A.; Olinski, R. \& Tudek, B. (2010). Oxidative stress and 8-oxoguanine repair are enhanced in colon adenoma and carcinoma patients. Mutagenesis, Vol. 25, No. 5, pp. 463-471, ISSN 1464-3804

Oh, Y.S.; Kim, E.J.; Schaffer, B.S.; Kang, Y.H.; Binderup, L.; MacDonald, R.G. \& Park, J.H. (2001). Synthetic low-calcaemic vitamin D(3) analogues inhibit secretion of insulinlike growth factor II and stimulate production of insulin-like growth factor-binding protein-6 in conjunction with growth suppression of HT-29 colon cancer cells. Mol Cell Endocrinol, Vol. 183, No. 1-2, pp. 141-149, ISSN 0303-7207

Park, J.H. (2008). Inhibition of colon cancer cell growth by dietary components: role of the insulin-like growth factor (IGF) system. Asia Pac J Clin Nutr, Vol. 17 Suppl 1, No., pp. 257-260, ISSN 0964-7058

Park, S.Y.; Nomura, A.M.; Murphy, S.P.; Wilkens, L.R.; Henderson, B.E. \& Kolonel, L.N. (2009). Carotenoid intake and colorectal cancer risk: the multiethnic cohort study. J Epidemiol, Vol. 19, No. 2, pp. 63-71, ISSN 1349-9092

Park, Y.; Spiegelman, D.; Hunter, D.J.; Albanes, D.; Bergkvist, L.; Buring, J.E.; Freudenheim, J.L.; Giovannucci, E.; Goldbohm, R.A.; Harnack, L.; Kato, I.; Krogh, V.; Leitzmann, 
M.F.; Limburg, P.J.; Marshall, J.R.; McCullough, M.L.; Miller, A.B.; Rohan, T.E.; Schatzkin, A.; Shore, R.; Sieri, S.; Stampfer, M.J.; Virtamo, J.; Weijenberg, M.; Willett, W.C.; Wolk, A.; Zhang, S.M. \& Smith-Warner, S.A. (2010). Intakes of vitamins $\mathrm{A}, \mathrm{C}$, and $\mathrm{E}$ and use of multiple vitamin supplements and risk of colon cancer: a pooled analysis of prospective cohort studies. Cancer Causes Control, Vol. 21, No. 11, pp. 1745-1757, ISSN 1573-7225

Penner, R.; Fedorak, R.N. \& Madsen, K.L. (2005). Probiotics and nutraceuticals: nonmedicinal treatments of gastrointestinal diseases. Curr Opin Pharmacol, Vol. 5, No. 6, pp. 596-603, ISSN 1471-4892

Petrik, M.B.; McEntee, M.F.; Johnson, B.T.; Obukowicz, M.G. \& Whelan, J. (2000). Highly unsaturated (n-3) fatty acids, but not alpha-linolenic, conjugated linoleic or gammalinolenic acids, reduce tumorigenesis in Apc(Min/+) mice. J Nutr, Vol. 130, No. 10, pp. 2434-2443, ISSN 0022-3166

Pot, G.K.; Geelen, A.; Majsak-Newman, G.; Harvey, L.J.; Nagengast, F.M.; Witteman, B.J.; van de Meeberg, P.C.; Hart, A.R.; Schaafsma, G.; Lund, E.K.; Rijkers, G.T. \& Kampman, E. (2010a). Increased consumption of fatty and lean fish reduces serum C-reactive protein concentrations but not inflammation markers in feces and in colonic biopsies. J Nutr, Vol. 140, No. 2, pp. 371-376, ISSN 1541-6100

Pot, G.K.; Habermann, N.; Majsak-Newman, G.; Harvey, L.J.; Geelen, A.; Przybylska-Philips, K.; Nagengast, F.M.; Witteman, B.J.; van de Meeberg, P.C.; Hart, A.R.; Schaafsma, G.; Hooiveld, G.; Glei, M.; Lund, E.K.; Pool-Zobel, B.L. \& Kampman, E. (2010b). Increasing fish consumption does not affect genotoxicity markers in the colon in an intervention study. Carcinogenesis, Vol. 31, No. 6, pp. 1087-1091, ISSN 1460-2180

Pot, G.K.; Majsak-Newman, G.; Geelen, A.; Harvey, L.J.; Nagengast, F.M.; Witteman, B.J.; van de Meeberg, P.C.; Timmer, R.; Tan, A.; Wahab, P.J.; Hart, A.R.; Williams, M.P.; Przybylska-Phillips, K.; Dainty, J.R.; Schaafsma, G.; Kampman, E. \& Lund, E.K. (2009). Fish consumption and markers of colorectal cancer risk: a multicenter randomized controlled trial. Am J Clin Nutr, Vol. 90, No. 2, pp. 354-361, ISSN 19383207

Prinz-Langenohl, R.; Fohr, I. \& Pietrzik, K. (2001). Beneficial role for folate in the prevention of colorectal and breast cancer. Eur J Nutr, Vol. 40, No. 3, pp. 98-105, ISSN 14366207

Rafter, J.; Bennett, M.; Caderni, G.; Clune, Y.; Hughes, R.; Karlsson, P.C.; Klinder, A.; O'Riordan, M.; O'Sullivan, G.C.; Pool-Zobel, B.; Rechkemmer, G.; Roller, M.; Rowland, I.; Salvadori, M.; Thijs, H.; Van Loo, J.; Watzl, B. \& Collins, J.K. (2007). Dietary synbiotics reduce cancer risk factors in polypectomized and colon cancer patients. Am J Clin Nutr, Vol. 85, No. 2, pp. 488-496, ISSN 0002-9165

Rao, C.V.; Hirose, Y.; Indranie, C. \& Reddy, B.S. (2001). Modulation of experimental colon tumorigenesis by types and amounts of dietary fatty acids. Cancer Res, Vol. 61, No. 5, pp. 1927-1933, ISSN 0008-5472

Reddy, B.S. (1999). Possible mechanisms by which pro- and prebiotics influence colon carcinogenesis and tumor growth. J Nutr, Vol. 129, No. 7 Suppl, pp. 1478S-1482S, ISSN 0022-3166 
Roberfroid, M.; Gibson, G.R.; Hoyles, L.; McCartney, A.L.; Rastall, R.; Rowland, I.; Wolvers, D.; Watzl, B.; Szajewska, H.; Stahl, B.; Guarner, F.; Respondek, F.; Whelan, K.; Coxam, V.; Davicco, M.J.; Leotoing, L.; Wittrant, Y.; Delzenne, N.M.; Cani, P.D.; Neyrinck, A.M. \& Meheust, A. (2010). Prebiotic effects: metabolic and health benefits. Br J Nutr, Vol. 104 Suppl 2, No., pp. S1-63, ISSN 1475-2662

Roynette, C.E.; Calder, P.C.; Dupertuis, Y.M. \& Pichard, C. (2004). n-3 polyunsaturated fatty acids and colon cancer prevention. Clin Nutr, Vol. 23, No. 2, pp. 139-151, ISSN 02615614

Samad, A.K.; Taylor, R.S.; Marshall, T. \& Chapman, M.A. (2005). A meta-analysis of the association of physical activity with reduced risk of colorectal cancer. Colorectal Dis, Vol. 7, No. 3, pp. 204-213, ISSN 1462-8910

Sanjoaquin, M.A.; Allen, N.; Couto, E.; Roddam, A.W. \& Key, T.J. (2005). Folate intake and colorectal cancer risk: a meta-analytical approach. Int J Cancer, Vol. 113, No. 5, pp. 825-828, ISSN 0020-7136

Sanjoaquin, M.A.; Appleby, P.N.; Thorogood, M.; Mann, J.I. \& Key, T.J. (2004). Nutrition, lifestyle and colorectal cancer incidence: a prospective investigation of 10998 vegetarians and non-vegetarians in the United Kingdom. Br J Cancer, Vol. 90, No. 1, pp. 118-121, ISSN 0007-0920

Sedelnikova, O.A.; Redon, C.E.; Dickey, J.S.; Nakamura, A.J.; Georgakilas, A.G. \& Bonner, W.M. (2010). Role of oxidatively induced DNA lesions in human pathogenesis. Mutat Res, Vol. 704, No. 1-3, pp. 152-159, ISSN 0027-5107

Shen, G.; Khor, T.O.; Hu, R.; Yu, S.; Nair, S.; Ho, C.T.; Reddy, B.S.; Huang, M.T.; Newmark, H.L. \& Kong, A.N. (2007). Chemoprevention of familial adenomatous polyposis by natural dietary compounds sulforaphane and dibenzoylmethane alone and in combination in ApcMin/+ mouse. Cancer Res, Vol. 67, No. 20, pp. 9937-9944, ISSN 0008-5472

Shukla, Y. \& Kalra, N. (2007). Cancer chemoprevention with garlic and its constituents. Cancer Lett, Vol. 247, No. 2, pp. 167-181, ISSN 0304-3835

Snow, D.R.; Jimenez-Flores, R.; Ward, R.E.; Cambell, J.; Young, M.J.; Nemere, I. \& Hintze, K.J. (2010). Dietary milk fat globule membrane reduces the incidence of aberrant crypt foci in Fischer-344 rats. J Agric Food Chem, Vol. 58, No. 4, pp. 2157-2163, ISSN 1520-5118

Song, J.; Sohn, K.J.; Medline, A.; Ash, C.; Gallinger, S. \& Kim, Y.I. (2000). Chemopreventive effects of dietary folate on intestinal polyps in Apc+/-Msh2-/- mice. Cancer Res, Vol. 60, No. 12, pp. 3191-3199, ISSN 0008-5472

Tammariello, A.E. \& Milner, J.A. (2010). Mouse models for unraveling the importance of diet in colon cancer prevention. J Nutr Biochem, Vol. 21, No. 2, pp. 77-88, ISSN 18734847

Tuohy, K.M.; Rouzaud, G.C.; Bruck, W.M. \& Gibson, G.R. (2005). Modulation of the human gut microflora towards improved health using prebiotics--assessment of efficacy. Curr Pharm Des, Vol. 11, No. 1, pp. 75-90, ISSN 1381-6128

van Duijnhoven, F.J.; Bueno-De-Mesquita, H.B.; Ferrari, P.; Jenab, M.; Boshuizen, H.C.; Ros, M.M.; Casagrande, C.; Tjonneland, A.; Olsen, A.; Overvad, K.; Thorlacius-Ussing, O.; Clavel-Chapelon, F.; Boutron-Ruault, M.C.; Morois, S.; Kaaks, R.; Linseisen, J.; 
Boeing, H.; Nothlings, U.; Trichopoulou, A.; Trichopoulos, D.; Misirli, G.; Palli, D.; Sieri, S.; Panico, S.; Tumino, R.; Vineis, P.; Peeters, P.H.; van Gils, C.H.; Ocke, M.C.; Lund, E.; Engeset, D.; Skeie, G.; Suarez, L.R.; Gonzalez, C.A.; Sanchez, M.J.; Dorronsoro, M.; Navarro, C.; Barricarte, A.; Berglund, G.; Manjer, J.; Hallmans, G.; Palmqvist, R.; Bingham, S.A.; Khaw, K.T.; Key, T.J.; Allen, N.E.; Boffetta, P.; Slimani, N.; Rinaldi, S.; Gallo, V.; Norat, T. \& Riboli, E. (2009). Fruit, vegetables, and colorectal cancer risk: the European Prospective Investigation into Cancer and Nutrition. Am J Clin Nutr, Vol. 89, No. 5, pp. 1441-1452, ISSN 1938-3207

van Kranen, H.J.; van Iersel, P.W.; Rijnkels, J.M.; Beems, D.B.; Alink, G.M. \& van Kreijl, C.F. (1998). Effects of dietary fat and a vegetable-fruit mixture on the development of intestinal neoplasia in the ApcMin mouse. Carcinogenesis, Vol. 19, No. 9, pp. 15971601, ISSN 0143-3334

Ventrella-Lucente, L.F.; Unnikrishnan, A.; Pilling, A.B.; Patel, H.V.; Kushwaha, D.; Dombkowski, A.A.; Schmelz, E.M.; Cabelof, D.C. \& Heydari, A.R. (2010). Folate deficiency provides protection against colon carcinogenesis in DNA polymerase beta haploinsufficient mice. J Biol Chem, Vol. 285, No. 25, pp. 19246-19258, ISSN 1083-351X

Vilar, E. \& Gruber, S.B. (2010). Microsatellite instability in colorectal cancer-the stable evidence. Nat Rev Clin Oncol, Vol. 7, No. 3, pp. 153-162, ISSN 1759-4782

Williams, C.D.; Satia, J.A.; Adair, L.S.; Stevens, J.; Galanko, J.; Keku, T.O. \& Sandler, R.S. (2010). Antioxidant and DNA methylation-related nutrients and risk of distal colorectal cancer. Cancer Causes Control, Vol. 21, No. 8, pp. 1171-1181, ISSN 15737225

Winkelmann, I.; Diehl, D.; Oesterle, D.; Daniel, H. \& Wenzel, U. (2010). Flavone induces changes in intermediary metabolism that prevent microadenoma formation in colonic tissue of carcinogen-treated mice. Mol Nutr Food Res, Vol. 54 Suppl 2, No., pp. S184-195, ISSN 1613-4133

Woodworth, H.L.; McCaskey, S.J.; Duriancik, D.M.; Clinthorne, J.F.; Langohr, I.M.; Gardner, E.M. \& Fenton, J.I. (2010). Dietary fish oil alters T lymphocyte cell populations and exacerbates disease in a mouse model of inflammatory colitis. Cancer Res, Vol. 70, No. 20, pp. 7960-7969, ISSN 1538-7445

World Cancer Research Fund \& American Institute for Cancer Research (2007a). The cancer process, In: Food, Nutrition, Physical Activity, and the Prevention of Cancer: A Global Perspective, World Cancer Research Fund, pp. 30-46, American Institute for Cancer Research, ISBN-13: 9780972252225, Washington DC, USA

World Cancer Research Fund \& American Institute for Cancer Research (2007b). Cancers; Colon and rectum, In: Food, Nutrition, Physical Activity, and the Prevention of Cancer: A Global Perspective, World Cancer Research Fund, pp. 280-288, American Institute for Cancer Research, ISBN-13: 9780972252225, Washington DC, USA

World Cancer Research Fund \& American Institute for Cancer Research (2007c). Foods and drinks, In: Food, Nutrition, Physical Activity, and the Prevention of Cancer: A Global Perspective, World Cancer Research Fund, pp. 66-196, American Institute for Cancer Research, ISBN-13: 9780972252225, Washington DC, USA 
World Cancer Research Fund \& American Institute for Cancer Research (2007d). Summary, In: Food, Nutrition, Physical Activity and the Prevention of Cancer: a Global Perspective, World Cancer Research Fund, pp. xiv-xxi, American Institute for Cancer Research, ISBN-13: 9780972252225, Washington DC, USA

Zeeb, H. \& Greinert, R. (2010). The role of vitamin D in cancer prevention: does UV protection conflict with the need to raise low levels of vitamin D? Dtsch Arztebl Int, Vol. 107, No. 37, pp. 638-643, ISSN 1866-0452

Ziech, D.; Franco, R.; Georgakilas, A.G.; Georgakila, S.; Malamou-Mitsi, V.; Schoneveld, O.; Pappa, A. \& Panayiotidis, M.I. (2010). The role of reactive oxygen species and oxidative stress in environmental carcinogenesis and biomarker development. Chem Biol Interact, Vol. 188, No. 2, pp. 334-339, ISSN 1872-7786 


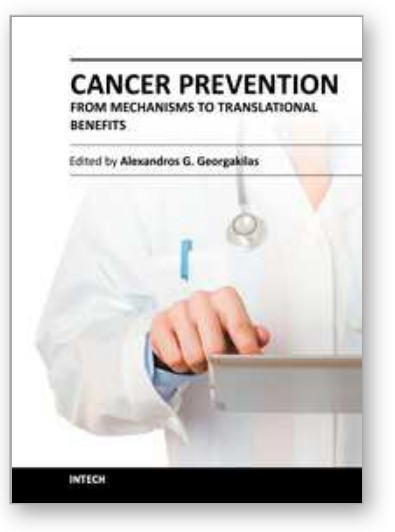

\author{
Cancer Prevention - From Mechanisms to Translational Benefits \\ Edited by Dr. Alexandros G. Georgakilas
}

ISBN 978-953-51-0547-3

Hard cover, 476 pages

Publisher InTech

Published online 20, April, 2012

Published in print edition April, 2012

This unique synthesis of chapters from top experts in their fields targets the unique and significant area of cancer prevention for different types of cancers. Perspective readers are invited to go through novel ideas and current developments in the field of molecular mechanisms for cancer prevention, epidemiological studies, antioxidant therapies and diets, as well as clinical aspects and new advances in prognosis and avoidance of cancer. The primary target audience for the book includes PhD students, researchers, biologists, medical doctors and professionals who are interested in mechanistic studies on cancer prevention and translational benefits for optimized cancer treatment.

\title{
How to reference
}

In order to correctly reference this scholarly work, feel free to copy and paste the following:

Sayori Wada (2012). Colorectal Cancer and the Preventive Effects of Food Components, Cancer Prevention From Mechanisms to Translational Benefits, Dr. Alexandros G. Georgakilas (Ed.), ISBN: 978-953-51-0547-3, InTech, Available from: http://www.intechopen.com/books/cancer-prevention-from-mechanisms-totranslational-benefits/colorectal-cancer-preventive-effects-of-food-components

\section{INTECH}

open science | open minds

\section{InTech Europe}

University Campus STeP Ri Slavka Krautzeka 83/A 51000 Rijeka, Croatia Phone: +385 (51) 770447

Fax: +385 (51) 686166 www.intechopen.com

\section{InTech China}

Unit 405, Office Block, Hotel Equatorial Shanghai No.65, Yan An Road (West), Shanghai, 200040, China 中国上海市延安西路65号上海国际贵都大饭店办公楼405单元 Phone: +86-21-62489820

Fax: $+86-21-62489821$ 
(C) 2012 The Author(s). Licensee IntechOpen. This is an open access article distributed under the terms of the Creative Commons Attribution 3.0 License, which permits unrestricted use, distribution, and reproduction in any medium, provided the original work is properly cited. 